\title{
WESTERN PLANT STUDIES. I
}

\section{Aven Nelson AND J. Francis Macbide}

[The last four numbers of "Contributions from the Rocky Mountain Herbarium" (IX-XII) were based largely upon the collections made by Mr. J. Francis Macbride in rgio and by Macbride and myself in rgir. During the season of I9I2, the field work was continued by MACBRIDE assisted during a part of the time by Mr. Dorman BennitT and by the writer. The territory covered was a small part of southwestern Idaho and certain parts of Nevada in and adjacent to the Humboldt National Forest. Our work in Nevada was greatly facilitated by the kindly assistance of the Forest Service, and we wish to acknowledge gratefully the many courtesies extended by Supervisor C. Sidney Tremewan and his assistants and foresters. The types, the numbers of which are given, were all collected by NELSON and MACBRIDE and are deposited in the Rocky Mountain Herbarium.

In working up the collections of I9I2, Mr. MACBRIDE has been associated with me, and the paper presented herewith is the result of this collaboration. This and other papers that we may publish jointly will be under the above title; while those for which I individually assume responsibility will be continued as "Contributions, etc."-Aven Nelson.]

Calochortus bruneaunis, n. sp.-Stems striate, minutely scabrous in lines, especially near the base, $2-4 \mathrm{dm}$. high, more or less tortuous: bulb narrowly oblong, covered with brown, dead scales, as is also the base of the stem: leaves several (4-6); the radical leaf nearly or quite equaling the plant; the cauline involute, expanded and scarious-margined at the sheathing base, $4^{-10} \mathrm{~cm}$. long: flowers I-3, axillary in the upper leaves: sepals rather broadly lanceolate, 2-3 cm. long, tapering gradually to a slender tip, colored like the petals within, green without but with a broad white scarious margin to above the middle: petals broadly obovate-cuneate, rather abruptly rounded above into a blunt point, longer than the sepals; body-color white, delicately streaked with green, with a green band from apex to the narrow yellow claw, just above which is a small purple inverted v-shaped or lunate blotch: petal wholly glabrous, even the small oblong gland at the summit of the short claw scarcely pubescent: anthers obtuse, purple, 6-8 $\mathrm{mm}$. long, about equaling the filaments: capsule narrowly oblong. 
This makes the third species in the green-banded group, the others being C. cyaneus A. Nels. and C. macrocarpus Dougl. The latter is the nearer relative to the species now proposed. C. bruneaunis is easily distinguished by the rather tortuous stems, the different color and marking of the flowers, and the glabrous petal faces.

No. I88I, found in chipped lava, high on the canyon sides of the "Hot Hole" of the East Bruneau, Owyhee County, Idaho, is the type.

Clematis aurea, n. sp.-Glaucous, climbing freely by the petiolules: stems glabrous, striate: leaflets broadly to narrowly lanceolate, petiolate, pale green, irregularly incisely dentate, acuminate-cuspidate, midvein prominent beneath: bud green, drooping, erect in anthesis, the four sepals then golden yellow, 4-5 $\mathrm{cm}$. long, oblong, obtuse, cuspidate, rather thick, prominently nerved, glabrous except for an incurved villous margin: the pubescent filaments dilated, $8-10 \mathrm{~mm}$. long, all antheriferous; anthers linear, about $5 \mathrm{~mm}$. long, obtuse, minutely cuspidate: achenes pubescent, the persistent black styles filiform, only moderately white plumose throughout, $4-5 \mathrm{~cm}$. long.

Collected in July 1909, at Challis, Custer County, Idaho. It was locally plentiful, clambering over rosebushes, etc., along a stream, and attracted attention by its unusual color and beauty. It is a member of the section VIORNA, though with sepals scarcely leathery. In aspect the plant more nearly resembles some members of the section ATragene.

Delphinium megacarpum, n. sp.-Much resembling $D$. Andersonii Gray, having a similar fascicle of long thickened woody roots and a strict mostly simple few-leaved stem: basal leaves petioled, from puberulent to nearly glabrous, suborbicular in outline, cuneately divided or parted, the lobes cleft into linear divisions; the stem-leaves rather remote, gradually reduced in size and number of lobes, puberulent or more usually sparsely hirsute-ciliate, the bracts and base of petioles conspicuously so: stems rather stout, ${ }^{2-} 5 \mathrm{dm}$. high, at first cinereous-puberulent to the base, becoming glabrate below in age: inflorescence narrow, racemose and usually with one or more slender erect floriferous branchlets from the uppermost axils: flowers dark blue: calyx softly hirsute, spur longer than the sepals and these exceeding the petals: carpels puberulent even at maturity, linear-oblong, $20-25 \mathrm{~mm}$. long, erect and parallel, 
only the tips divaricate, reticulately veined: seed-body large, dark, narrowly winged on the margins and with a depressed summit.

This species has passed for $D$. Andersonii and is a close relative of it. The typical form of that seems to be confined to western Nevada and adjacent California. Taking those characters on which-Dr. Gray laid stress, namely, "very glabrous"; "follicles oval or oblong, not over half an inch in length"; "seed body small and broadly winged," as diagnostic, one is almost forced to separate this pubescent long-carpelled form. The segregate occurs in interior northern Nevada, Idaho, and adjacent Oregon. No. 1779, House Creek, Idaho, June 29 , I9I 2 , is the type number.

Arabis Menziesir lata, n. var.-Closely allied to the species, but the pods broader (as much as $6 \mathrm{~mm}$.) $2.2 \cdot 5 \cdot 4.5 \mathrm{~cm}$. long, usually about twice as long as the pedicels; style nearly wanting.

As shown in Proc. Biol. Soc. Wash. I7:91 and 18 : 187 , the Phoenicaulis section of Parrya is less aberrant in Arabis than in Parrya. Typical Arabis (Parrya) Menziesii will not run to Parrya by any of the keys to the cruciferous genera, but does run to Arabis by most, if not all, of such keys. The variety here described is probably the P. Menziesii of Bot. King Rep. I4, in part.

Fully mature material is our no. 1838 , from lava cliff pockets, House Creek, Idaho, June 30, I9I 2.

Arabis Pedicellata A. Nels., Proc. Biol. Soc. Wash. I7:9I is Parrya Menziesii lanuginosa Wats., and may best become Arabis Menziesir lanuginosa.

Horkelia beneolens, n. sp.-Caudex simple or branched, more or less fleshy or becoming woody, thick because of the dense coat of dead brown petioles, the flaccid sordid herbage clammy with a short glandular pubescence: stems few-several from each crown, sparingly leafy, $7^{-15} \mathrm{~cm}$. long including the rather open inflorescence: leaves several from each crown, mostly oblong, with $5^{-9} 9$ pinnae, on slender petioles: pinnae $7^{-15} \mathrm{~mm}$. long, alternate or irregularly opposite, oblong, flabelliform or suborbicular, more or less deeply palmately parted into oblong obtuse or acutish lobes; stem-leaves short, with fewer pinnae $\left(3^{-5}\right)$ and short petioles (or subsessile); stipules ovate-oblong: flowers few-many on slender pedicels in an open cyme: calyx rotate, with flat pentagonal hypanthium with a marginal flange giving a sunken or inverted salverform effect (as in the base of the calyx of some species of Physalis in fruit); lobes ovate, acute, about $3 \mathrm{~mm}$. long, fully twice as long 
as the small linear-oblong bractlets: petals white, shorter than the lobes of the calyx, the small linear-lanceolate blade scarcely longer than the slender claw: stamens 5 ; the brown anthers subspherical, their cells opening lengthwise: pistils $3-5$, sometimes all maturing: achenes large $(2 \mathrm{~mm}$. long), flattened, ovoid, with the inner edge nearly straight, noticeably longitudinally ridged on the surface.

This plant has the foliage of some of the sections of Horkelia, the numerical plan of certain species of Ivesia, while the calyx characters come nearest to Comarella. Unfortunately this cannot get into that genus since in it the petals are red and the pistils only two. On the whole the plant here described probably comes nearest to Horkelia Baileyi (Wats.) Rydb. The specific name chosen refers to the delightful fragrance emitted by the plant.

It does not seem possible to maintain these three genera in view of the increasing number of species that show characteristics that overlap the generic bounds. In fact, what character, except the open space between pistil-bearing receptacle and the margin of the hypanthial disk, separates any of them constantly from Potentilla? Agreeing in this one character and overlapping as to other characters, it is in the interest of simplicity to let Horkelia include them all.

No. 1708 , Castle Ford, on the Salmon, in Idaho, is the type. It was found hanging in wet crevices on the vertical faces of basaltic cliffs, June 25 , I912.

Potentilla glomerata dichroa, n. comb.-Potentilla dichroa Rydb. N. A. Fl. 22:319. 1908.

This is distinguished from the species only by the denser tomentum on the under side of the leaves and the grayer color of the plant as a whole.

Astragalus owyheensis, n. sp.-Spreading, prostrate, manystemmed perennial, tufted at base, minutely and sparsely strigillose, the slender wiry stems, including the open racemes, $2-6 \mathrm{dm}$. long: stipules triangular, the lower about $3 \mathrm{~mm}$. long and scarious, upward becoming smaller and green: leaves 6-10 $\mathrm{cm}$. long, rather irregularly pinnate; the leaflets $\left(5^{-1} 3\right)$ remote, shorter than the internodes, linear: the very open axillary racemes exceeding the leaves: the slender pedicels $3-6 \mathrm{~mm}$. long: calyx finely strigillose with intermingled black hairs, the subulate teeth about one-third as long: flowers 8-10 $\mathrm{mm}$. long, white; standard $5 \mathrm{~mm}$. wide, rather deeply emarginate, the edges strongly recurved, forming two crests at the edge near the middle of the blade: wings not emarginate, narrowly obovate, the edges incurved: keel shorter, with a broad 
rounded incurved apex: pod oblong-linear, pubescent like the plant, shortly acute, Io-18 $\mathrm{mm}$. long, straight or slightly curved, usually recurved but sometimes ascending, one-celled, the dorsal suture being but slightly intruded: seeds few (about 5).

Perhaps this finds its nearest relatives in A. atratus Wats. and A. obscurus Wats. No. I887, collected July 2, I9I 2, above the "Hot Hole" of the East Bruneau, Owyhee Co., Idaho, is the type. It was quite inconspicuous because of its color and its habit of creeping among the short grasses of the sagebrush plains.

Geranium caespitosum gracile, n. comb.-G. gracile Engelm. in Gray Pl. Fendl. 27. I849; G. atropurpureum Heller, Bull. Torr. Bot. Club 25: 195. I898; G. furcatum Hanks, N. A. Fl. 25: 6. 1907 .

Specimens of $G$. caespitosum when they show a tendency to become glandular pubescent on the pedicels have been considered as G. gracile (G. atropurpureum), and if this glandulosity extends to the stem they are G. furcatum. A series of specimens can be so arranged as to show all degrees of glandulosity to the complete lack of it. The proposed variety, therefore, rests primarily upon the slenderer and more erect stems, the narrower petals, and usually a trace of glandulosity. Where the glandulosity becomes marked throughout, it merges into G. Parryi (Engelm.) Heller.

It is somewhat singular that there should be any misunderstanding in regard to Geranium caespitosum James. Admitting that the original printing of the name did not publish the species, Dr. Gray's diagnosis in Pl. Fendl. 25 and Dr. Trelease's in Bost. Soc. Nat. Hist. 4:72 fixed the plant to which this name must apply.

Specimens answering to this description are not rare in the herbaria and are always non-glandular and with the pubescence of the stem (whether sparse or abundant) more or less retrose. The plant is always cespitose, growing in the form of a turf or mat from which short assurgent stems arise. The new characterization in the N. A. Fl. 25: 15 would seem to be without warrant, and at best that description presents merely one of the variants of $G$. Fremontii Torr.

Specimens wholly typical of $G$. caespitosum are BAKER 448, Colorado; Baker, EARle, and Tracy 407, Colorado; II 55 from Colorado, distrib. by the New York Bot. Gard. as one of the type nos. of G. Cowenii Rydb.; Buffum, Wyoming; Nelson 859r, Wyoming; Metcalf r94, New Mexico; Macdougal I 8, Arizona. Besides G. Cowenii, G. marginale Rydb. must undoubtedly be referred to $G$. caespitosum as here understood.

GENTIANA AFFINIS major, n. var.-Leaves uniformly narrower: calyx lobes oblong-lanceolate, nearly equal and all approximately 
equaling the tube: corolla broadly funnelform, larger, diameter at the top more than $2 \mathrm{~cm}$.; the plaits purple, alternating with green bands extending downward from the lobes, the sinuses short.

This would be a good species if all degrees leading to the above characters were not present in a collection of $G$. affinis. Collected at Mountain City, Elko Co., Nevada, August 9, I9г 2, no. 2 I 78.

Nemophila explicata, n. sp.-Branching from the base; the branches sometimes sparingly branched, $7^{-I_{5}} \mathrm{~cm}$. long, spreading or weakly erect, glabrate, the scattering hairs short and refracted: leaves obovate or orbicular in outline, cuneately tapering into a margined petiole one-fourth to one-half as long as the blade, crenately $3-5$-lobed, Io- $20 \mathrm{~mm}$. long, sparsely strigulose with more or less appressed hairs: pedicels $7-\mathrm{I} 4 \mathrm{~mm}$. long, at length more or less reflexed or even refracted: flowers small, not white; calyx appressed strigulose, in fruit $2 \mathrm{~mm}$. or scarcely more long; its tube short; its lobes ovate, sparsely short ciliate on the margins, its appendages small, oblong, as long as the tube: corolla small, barely exceeding the calyx, tubular-campanulate, its oval lobesal most as long as the tube, the plicae or appendages wholly wanting: style short, divided at apex only: capsule $3-4 \mathrm{~mm}$. long, more or less appressed cinereous-strigulose: seeds 4 , large, $3 \mathrm{~mm}$. long, irregular quadrants, slightly roughened, pale yellow with numerous small brownish dots or obscurely pitted; the membranous cellular caruncle caplike.

Secured at Jarbidge, in the canyon of the East Bruneau River, among shalelava, growing with $N$. breviflora Gray. Only one other of the described species seems to be devoid of appendages in the corolla tube. No. 2229, July 7 , I9I 2 , is the type.

Phacelia foliosepala, n. sp.-Slender annual, $7^{-12} \mathrm{~cm}$. high, hirsute-pubescent and glandular, trichotomously branched (candelabra-like) twice or thrice, the branches usually simple, floriferous to near their bases: leaves few, scattering, $I-I .5 \mathrm{~cm}$. long, oblanceolate, obtuse, tapering below to a short margined petiole: inflorescence racemose, rather open in fruit (flowers unknown): pedicels about $2 \mathrm{~mm}$. long: calyx lobes foliar, unequal, resembling the leaves, Io- $55 \mathrm{~mm}$. long, more than twice as long as 
the capsule: capsule oval: seeds 12 , irregularly ellipsoidal, beautifully alveolate, seal brown when mature.

Possibly this may best be referred to the section EuToca Gray, but even in this section there seems to be no species nearer to it than P. linearis (Pursh) Holz. That, however, is a very different plant in its mode of branching, in its different and glandless pubescence, and probably in all of its floral parts as it evidently is in its calyx. It is interesting that this little annual possessed (according to the field notes) a "strong vile odor, something fierce," reminding one of those perennials like GoodDing's $P$. foetida that proclaim their identity while they are still a long way off.

The type is no. 2232, Gold Creek, Nevada, July 27, I912; moist sunny flat.

Oreocarya cilio-hirsuta, n. sp.-Biennial or, apparently, sometimes perennial, from a slender taproot more or less branched at summit; the branches of the caudex or crown short and clothed with the inordinately crowded linear leaf-bases: stems severalmany, very slender, somewhat angled, greenish but thinly hirsute and with an admixture of long white stiff ciliate-appearing hairs, I $5-30 \mathrm{~cm}$. long and floriferous in the axils for half their length: crown leaves very numerous, $2-4 \mathrm{~cm}$. long, linear, the upper part more or less spatulate and not more than half as long as the slender petiolar portion; cauline shorter, mostly broadly linear; all with pubescence similar to that of the stems: the rather small axillary thyrsoid clusters IO-I5, crowded above, more open below and usually surpassed by the foliar bracts: inflorescence moderately hirsute-hispid: calyx lobes linear-lanceolate, $6-8 \mathrm{~mm}$. long in fruit: corolla tube barely as long as the calyx, its lobes suborbicular, half as long as the tube: nutlets ovate as to the body but narrowed and subacute at apex, bordered by a filiform wing-margin, sparsely but sharply muriculate on the back, even more minutely on the ventral side, not at all rugulose; scar linear, nearly as long as the nutlet, slightly enlarged at the base but not forked.

The type is no. I799, from Minidoka, Idaho, June 23, I912, where it was growing in the loose sagebrush soil. MACBRIDE's no. 93 from New Plymouth, May 21, 1910, and his no. 875, from Sand Hollow, June 2, I9II, were distributed as $O$. affinis and $O$. affinis perennis respectively. Neither of these accord very closely with the species to which they were referred, and although not identical with the species here proposed, they will probably have to be considered a part of it rather than of $O$. affinis. 
Castilleja miniata Dougl.- - Special effort was made to secure as full a series as possible in this genus in order to see something of the degree of variability within specific lines. No species shows how great this variability is better than C. miniata. Incidentally it may be remarked that the making of synonyms is not always due to the variability in the specimens representing a species, but quite as often to errors in the original descriptions which authors continue to copy and with which we constantly compare new material. Another source of error is found in the habit, more or less prevalent, of naming up material by comparison alone. $A$ has a specimen slightly aberrant; $B$ names his by comparison with $A$ 's, and lets it pass though evidently somewhat different; $C$, having $B$ 's plant, names his material accordingly, and so on. Look through any well filled species cover and see these facts illustrated.

In the original description of $C$. miniata the galea is said to exceed the corolla tube. On the assumption that this was so for the species (it probably was on the type sheet) some segregates have been made by various authors that had better not have been made. C. miniata material measured by this yardstick contains few (if any) specimens that are typical. Dr. RyDBERG, for example, in working all the material for his Flora of Montana had but one number (Rydberg and Bessey 4965, Wolf Creek, 1897). Unfortunately, too, other sheets of even this same number (4965) show only corollas in which the galea is shorter than the tube. The character is therefore more or less unreliable in this species, and hence probably in others.

Another character in Castilleja which is often misinterpreted is the root system. Collectors almost always pull the stems loose from the root or caudex. Being usually numerous in the clumps they are decumbent at base, and more or less rooted at the lower nodes. This often gives them the appearance of having been detached from a running rootstock when such was not the case.

Of course it is generally known that the color of the bracts varies, and this gives the plants a very different look even when the color of calyx and corolla remains (as it should) fairly constant.

These observations were induced by the necessity of distributing several of our numbers as $C$. miniata in spite of the fact that they refuse to accord fully 
with the hypothetical type. For example, our nos. 213I and 2132 , growing together in "placer wash," agree in having a large intricately branched root, from the crown of which the stems spring. Both have corollas with the galea yellowish-green, scarcely as long as the tube, but our field notes read as follows: " 203 I, bracts most remarkably bright red; 2132 , bracts a splendid golden yellow with orange tips." No one studying these two critically can fail to decide they are the same species, and can scarcely fail to refer them to $C$. miniata.

Castilleja Bennittii, n. sp.-Very short-lived perennial, sparsely hirsute throughout with a short dense cinereous subscabrous indument underneath: stems few, simple or often branched, ${ }_{2-3} \mathrm{dm}$. high: leaves linear, entire or irregularly lobed, the lobes narrower than the blade: inflorescence dense, becoming more open and slender in age, old rose in color: bracts three-cleft, the lobes blunt, the middle the largest: calyx $\mathrm{I}_{5}^{-20} \mathrm{~mm}$. long, the subequal clefts only about $5 \mathrm{~mm}$. deep, these divisions shallow-lobed, the short rounded lobes terminating the prominent ciliate calyx nerves: corolla slightly, sometimes scarcely, exserted, $15^{-22} \mathrm{~mm}$. long; the galea about half as long as the tube, the short rounded teeth hardly differentiated in the strongly nerved saccate lower lip.

There seems to be no near relative to which to ally this species, unique in its color and floral parts. It was pronounced new in IgII on the strength of specimens submitted by Dorman BenNITT of Twin Falls. It is a pleasure to dedicate it to its discoverer, who accompanied the, collectors on part of the 1912 trip and assiduously assisted in the field work. The type is no. 17 I4 secured on the sagebrush plains of Shoshone and Twin Falls, June 24, I9I2.

Castilleja RHEXIfolia pubens, $n$. var.-The branches of the caudex and the stem-bases scaly: stems numerous (usually several of them short and sterile), with a villous crisped pubescence quite to their bases: lower leaves also with a similar, though shorter pubescence.

No. 2023 , on stony brush slopes, from Jarbidge, Nevada, July II, I912, is taken as the type.

Castilleja curticalix, n. sp.-Plants harsh to the touch, often decidedly so, in rather small clumps, from short-lived perennial roots: stems few-many, $2-4 \mathrm{dm}$. high, simple or nearly so, softly cinereous-hirsute near the base, becoming glabrate upward: leaves 
numerous, scarcely smaller above, often rather closely ascending, scabrous on both sides, sometimes ciliate on the margins, linear to narrowly lanceolate, $2-6 \mathrm{~cm}$. long, usually entire, but not rarely with one pair of widely divaricate lobes: bracts resembling the leaves: the moderately crowded inflorescence at length rather open, predominating color yellow or greenish-yellow, but often flushed with red: calyx I. $5 \mathrm{~cm}$. long, scarcely exceeding the corolla tube, subequally cleft above and below, the primary divisions cleft at apex into long acute teeth: corolla $2-2.5 \mathrm{~cm}$. long, galea 7 -ro $\mathrm{mm}$. long, the lower lip scarcely saccate, with very short teeth, the outer the longer.

Apparently the nearest allies of the proposed species are $C$. fasciculata A. Nels. and $C$. lutescens (Greenm.) Rydb. It differs from both in the very short calyx, also from the former in the harsh pubescence (in which it resembles $C$. lutescens), and from the latter in the narrower leaves. No. 2099 from Gold Creek, Nevada, July 24, I9I 2, is taken as the type. No. 2098 from the same locality and 1983 from Jarbidge, July 8 , are both fairly representative. It occurs mostly on grassy slopes.

Castilleja fasciculata inverta, n. var.-Much resembling the species, but pubescence merely a fine puberulence: calyx exceeding the corolla, more deeply cleft above than below, its lobes shortbifid: galea and lip subequal.

Practically all the perennial species formerly referred to Orthocarpus have been transferred to Castilleja, even when the corolla lips are subequal. This seems advisable, the more so in the present instance, because of its evident affinity with $C$. fasciculata A. Nels. In the subequal lips of the corolla, which is surpassed by the calyx, the proposed variety is strongly differentiated, and if subsequent collections show the characters given above to be constant it will become $C$. inverta.

Secured at Rattlesnake Springs, Idaho, on hard gravelly soil among the sagebrush, no. I9I5, July 4, I9I2.

Pentstemon rex, n. sp.-Having the pubescence, herbage, and aspect of $P$. perpulcher A. Nels., Bot. Gaz. 52:273. I9II.-Corolla bright blue, about $3.5 \mathrm{~cm}$. long, rather abruptly ampliate above the tube proper, wholly glabrous without and within as are also the anthers: sterile filament slightly dilated, glabrous or sparsely hispidpubescent with short unequal hairs: anther cells dehiscent from the base upward for about three-fourths their length, leaving a closed saccate apical portion. 
This could be referred to $P$. perpulcher were it not for the strong contrast between its rather small flowers and the large showy ones of this. Then the dehiscence character is unique in the $P$. glaber group. Some of the red-flowered species of Pentstemon, recently erected into a separate genus by Dr. Greene, have anthers in which the upper portion of the cells remain closed and saccate, but none are known to the writers in the other sections of the genus. The SACCANTHERA section, of course, has anthers in which the base of the cell is the part that remains closed.

The following four numbers are all representative, but the first is named as the type: no. I999, Jarbidge, Nevada, July 9, I9I2; no. 977, Macbride, Twilight Gulch, Owyhee Co., Idaho, June 23, rgro (distributed as P. speciosus Dougl.); 1774, House Creek, Owyhee Co., Idaho, June 29, I912; 2157, Bieroth's Ranch (McDonald Creek), Nevada, August 2, I9I 2.

PentSTEMON PERPULCHer pandus, n. var.-Smaller than the species, the leaves more or less curved or arcuate: puberulence very dense, that of the stem extending to the rachis but not to the pedicels and calyx.

No. 1884 , July 2, I91 2 , on the high plains, near the "Hot Hole" of the East Bruneau is the type.

Downingia brachyantha (Rydb.), n. comb.-Bolelia brachyantha Rydb., Mem. N.Y. Bot. Gard. r:458. 1900.

Downingia corymbosa (A. DC.), n. comb.-Clintonia corymbosa A. DC. Prodr. 7:347. I838.

Because of some splendid specimens secured of these species in the field work of $19 \mathrm{I}_{2}$, our attention has been called to the fact that in accordance with the action of the Vienna Congress ("nomina conservanda") these species must be transferred.

Erigeron elkoensis, n. sp.-Plant low, subcinereous with a rather dense short more or less retrose pubescence throughout, with a short simple or sparingly branched caudex clothed with dead leafbases: stems few, simple, decumbent-ascending, monocephalous, leafy throughout or often naked-pedunculate above, about $4^{-10}$ $\mathrm{cm}$. long: leaves numerous on the crowns, $2-4 \mathrm{~cm}$. long including the petiole, oblong-spatulate, subacute, tapering to a narrowly winged petiole as long as or longer than the blade, inclined to be conduplicate; stem leaves similar, becoming smaller upward and linear: heads large, $20-25 \mathrm{~mm}$. broad: bracts lance-linear, acute, unequal, one-nerved, in ${ }^{2-3}$ series, the inner scarious-margined, 
entire or fimbriate, granular-glandular, the outer green, hirsute as well as glandular: rays $I_{5-20}$, conspicuously purple, rather broad, 3-toothed at apex: disk flowers yellow: achenes (young) pubescent.

In habit this suggests $E$. leiomeris Gray, but in other respects is very different. No. 2068, secured on open pebbly slopes, near Pole Creek in the Burnt Timber Mountains, Elko Co., Nevada, is the type.

ERIGERON POLIOSPERMUS latus, n. var.-Rougher pubescent than in the typical form, the crowns of the caudex clothed with dead leaf-bases: leaves unusually broad ( $3-4 \mathrm{~mm}$.): heads large, very broad (the disk about $x_{5} \mathrm{~mm}$.) and the rays rather long and broad: involucre sparsely hispid, with the tips of the bracts granular-glandular, otherwise nearly or quite naked: rays purplish to white: achenes brown, glabrate.

This was a most striking plant on the black volcanic sands on which it was secured. In habit and aspect it suggested the E. compositus group rather than its real affinity, and led to its being tentatively designated as a species, E. latus. The technical characters, however, scarcely warrant such a disposition. Three Creek, Owyhee Co., Idaho, no. I86ı, July I, I9I 2.

Rocky Mountain Herbarium UNIVERSITY OF WYOMING, LARAMIE 


\section{$2 \mathrm{BHL}$ Biodiversity Heritage Library}

Nelson, Aven and Macbride, J. Francis. 1913. "Western Plant Studies. I." Botanical gazette 55(5), 372-383. https://doi.org/10.1086/331067.

View This Item Online: https://www.biodiversitylibrary.org/item/109454

DOI: https://doi.org/10.1086/331067

Permalink: https://www.biodiversitylibrary.org/partpdf/223507

\section{Holding Institution}

Missouri Botanical Garden, Peter H. Raven Library

\section{Sponsored by}

Missouri Botanical Garden

\section{Copyright \& Reuse}

Copyright Status: Public domain. The BHL considers that this work is no longer under copyright protection.

This document was created from content at the Biodiversity Heritage Library, the world's largest open access digital library for biodiversity literature and archives. Visit BHL at https://www.biodiversitylibrary.org. 